\title{
Exposomes and metabolic health through a physical activity lens: a narrative review
}

\author{
Shelley Gorman (1) A Alexander N Larcombe $\mathbb{D} 2,3$ and Hayley E Christian』1 \\ 1Telethon Kids Institute, University of Western Australia, Perth, Australia \\ ${ }^{2}$ Telethon Kids Institute, Perth, Australia \\ ${ }^{3}$ School of Population Health, Curtin University, Perth, Australia
}

Correspondence should be addressed to S Gorman: shelley.gorman@telethonkids.org.au

\begin{abstract}
In this narrative review, we provide an overview of the role of physical activity as part of differing exposomes (our combined non-genetic exposures from conception onwards) and environmental influences on metabolic health. We discuss 'beneficial' exposomes (green/natural outdoor spaces, sun exposure, healthy diets and features of built environments) that could synergise with physical activity to prevent metabolic dysfunction, particularly that related to lifestyle diseases of obesity, type 2 diabetes and metabolic syndrome. Physical activity may also reduce the capacity of some adverse exposomes, specifically those with significant levels of air pollution, to contribute towards metabolic dysfunction. Other exposomes, such as those experienced during pandemics (including COVID-19), potentially limit opportunities for physical activity, and there may be unexpected combined effects of physical activity with other infections (e.g. adenovirus-36) on metabolic health. Finally, we discuss how environments could be better optimised to create exposomes that promote the health benefits of physical activity and likely future directions of this research field.
\end{abstract}

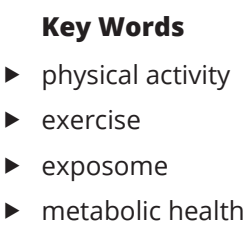

Journal of Endocrinology (2021) 249, R25-R41

\section{Introduction}

Physical activity is essential for good health

The beneficial effects of physical activity are clear for metabolic and overall health. It is advocated by the World Health Organisation, International Society for Physical Activity and Health, Obesity Society and many agencies and government health bodies around the world as an important means of reducing the risk of developing metabolic dysfunction. Indeed, physical activity reduces the risk of developing at least 35 chronic diseases (Booth et al. 2012), including, type 2 diabetes, non-alcoholic fatty liver disease, cardiovascular disease, as well as some cancers, while also contributing towards bone mineral density, brain and mental health, and mobility (McGee \& Hargreaves 2020, Thyfault \& Bergouignan 2020). Many of these chronic diseases are underpinned by metabolic dysfunction and are increasing in prevalence in countries across the world. Therefore, developing targeted and better-defined lifestyle approaches that more effectively prevent or treat the harms of metabolic dysfunction are warranted. Advice to increase physical activity levels is routinely given as part of lifestyle approaches towards reducing metabolic dysfunction. Even relatively small amounts of activity (e.g. >3500 steps/day) may be protective (Fretts et al. 2012), although many public health and health promotion programs promote much more (i.e. $\geq 10,000$ steps/day). Physical activity regulates insulin sensitivity (how sensitive the body is to insulin for control of blood glucose) and systematic metabolism via acute and chronic adaptations, which are underpinned 
by inter-tissue communications that prevent metabolic derangement (Thyfault \& Bergouignan 2020). Welldescribed adaptations by skeletal muscle are likely complemented by adaptations in many tissues (including liver, heart, pancreas, gut and brain) controlled by the interplay of potentially thousands of exercise-induced mediators to prevent excessive inflammation and oxidative stress and promote insulin signalling (McGee \& Hargreaves 2020, Thyfault \& Bergouignan 2020). In this review, we explore how differing environmental conditions and exposomes could modulate the capacity of physical activity to affect metabolic health.

\section{Physical activity in differing environments}

Determining how physical activity could be best tailored to treat chronic metabolic disease is an important research focus, with ongoing consideration of what are the best approaches, including exercise modality/type (e.g. resistance vs aerobic), intensity, frequency and duration and complementary nutritional approaches (McGee \& Hargreaves 2020, Savikj \& Zierath 2020). Where physical activity takes place is another important consideration. There is emerging evidence of the impact of environmental influences - including air pollutants ( $\mathrm{Li}$ et al. 2019, Yang et al. 2020) and sun exposure (Gorman 2020) - on metabolic health. These exposures modulate metabolic health in differing directions, with harms described for air pollution, and some benefits for lowlevel (non-burning) sun exposure. Similar to physical activity, both exposures affect metabolic processes in a variety of tissues, acting through an array of interacting mediators that affect pro-inflammatory and oxidative stress pathways, in addition to other novel effects on liver lipid turnover and the gut microbiome (Li et al. 2019, Feng et al. 2020, Gorman 2020, Vogel et al. 2020). How these exposures - and their induced mediators - interplay with physical activity to affect metabolic health is yet to be fully defined, and further research is needed to determine the best conditions in which to undertake the exercise for prevention and treatment of metabolic dysfunction.

One increasingly important example of metabolic dysfunction is metabolic syndrome, a cluster of conditions (high blood pressure, high blood glucose, abdominal adiposity and hyperlipidaemia) that increase the risk of heart disease, stroke and type 2 diabetes (Grundy et al. 2004). Regular moderate-intensity physical activity is consistently associated with a lower prevalence of metabolic syndrome; however, higher intensity vigorous physical activity (and the associated increase in cardiorespiratory fitness) may provide greater benefit (Churilla \& Zoeller 2008, Zhang et al. 2017, Amirfaiz \& Shahril 2019). There is little evidence for significant associations with light-intensity physical activity (Amirfaiz \& Shahril 2019), yet increased sedentary time is positively associated with metabolic syndrome (Guinhouya et al. 2011, Amirfaiz \& Shahril 2019). These associations appear to be similar in adults and youth (Guinhouya et al. 2011, Amirfaiz \& Shahril 2019). Finally, physical activity is associated with a number of individuals (self-efficacy, motivation, intention and other related personal beliefs), social (support from family, friends, and work; wider community and organisational norms and practices) and physical (neighbourhood walkability, access to vegetation, high-quality parks and recreational facilities, aesthetics, crime and safety) environmental factors (Trost et al. 2002, Bauman et al. 2012) that could modulate the nature of its associations with metabolic dysfunction.

\section{What are exposomes?}

The exposome includes all environmental (i.e. nongenetic) exposures that are received by a person throughout their life, from conception onwards (Wild 2005). These accumulate and interact together with a person's genome to affect their health and development (Nieuwenhuijsen 2016). Characterisation of exposomes includes 'bottom-up' approaches, which attempt to measure the environment a person lives in, and 'top-down' approaches, which focus on measuring a person's direct exposures. This may be done through characterisation of metabolites present in blood (Rappaport 2011), and/ or by dosimetry (e.g. actigraphy for physical activity; radiation dosimetry for sun exposure) (Drewnowski et al. 2020). Recent research, in particular, has focused on metabolomic (measurement of metabolites in a specimen) approaches to better understand the effects of exposomes on health (Rattray et al. 2018). These often provide information on the exposures, but not necessarily their sources (Rappaport 2011), especially those influenced by human behaviours. A good example of this is 25-hydroxyvitamin $\mathrm{D}$, the metabolite used to determine vitamin D status and an important determinant of bone health (Bouillon et al. 2019). Levels of this metabolite are well-known to be influenced by sun exposure, vitamin D supplementation and diet; however, 25-hydroxyvitamin D levels are likely also influenced by ill health (Autier et al. 2014) and physical activity (Abboud et al. 2017, Sun et al. 2017, 2018). Using 25-hydroxyvitamin D as a proxy for sun exposure only, likely underestimates the 
influence of other elements of the exposome. Therefore, environmental health studies that combine approaches that characterise both the environment a person lives in, and their personal exposures (merging metabolomics, genomics and dosimetry) are essential to define the best environments and means to promote optimal health.

\section{The exposome and metabolic dysfunction}

In addition to air pollution and sun exposure, environmental influences on metabolic health include factors that likely affect our capacity to undertake physical activity, such as walkability (how easy it is to walk in a given area), green space and other resources and elements (e.g. noise pollution, crime, safety) of the built environment, as well as weather and geographyrelated impacts (e.g. season, day length, altitude) (Dendup et al. 2018). Other risks include personalised exposures such as diet and intake of alcohol and caffeine, endocrine (metabolic) disruptors, physical inactivity and sedentary activities, social networks, lifestyles that affect circadian rhythm (e.g. shift work), socioeconomic status and education (Bhatnagar 2017, Bellou et al. 2018, Le Magueresse-Battistoni et al. 2018). Importantly, multiple methodological issues still impede our capacity to demonstrate causality in this space, with most investigations utilising cohort (longitudinal, crosssectional) or ecological data. Similarly, how applicable findings collected to-date are for people living in different environments across the world is uncertain, as most have been reported from people living in high-income settings (reviewed by Dendup et al. 2018, DeFlorio-Barker et al. 2020).

\section{Physical activity within exposomes and effects on metabolic health}

In this narrative review, we apply a 'physical activity lens' to provide an overview of the impacts of physical activity on metabolic health in differing exposomes (and vice versa). Our intention was to provide a narrative review and perspective of this broad field, describing current research foci and highlighting possible new avenues of research. These include consideration of understudied topics, or unknown interactions between certain exposomes/elements within exposomes, with physical activity and metabolic health. A literature search was conducted on PubMed (until 1 August 2020) in which the following keywords were combined: (physical activity, exercise) AND (exposome) AND (addiction, air pollution, alcohol, altitude, bad habits, beverage, built environment, clean air, cigarette, climate change, circadian, crime diet, diurnal, drug abuse, education, e-cig(arette), endocrinedisrupting chemical, fat, fire, fructose, gluten, global warming, green space, healthy diet, heat, humidity, latitude, light at night, Mediterranean diet, melatonin, opioid, poverty, prescription drug, prescription medicine, processed, recreation(al) drug, remote, rural, safety, salt, smoking, socioeconomic status, sugar, sun exposure, sweetened, temperature, tree, ultraviolet, unhealthy diet, urban, violence, volatile organic compounds, walkability OR water). For some searches, no articles were identified including combinations with the search terms/phrases: circadian, crime, diurnal, drug abuse, light at night, melatonin, opioid, prescription drug, recreation(al), safety, and violence. Overall, this search strategy yielded 36 publications in total, including 21 primary articles, and 15 reviews/other articles. All articles from these searches were reviewed, with 26 (17 primary research articles and 9 review articles) cited in this narrative review. Reasons for excluding the remaining 10 articles included: findings not specific to metabolic health (4 primary articles); and articles that did not provide insights specific to metabolic health and physical activity or referred to primary articles identified through the search conducted above (which were instead cited below) (6 reviews/other papers). Only papers published in English were included. Identified research was categorised into several themes including: (i) beneficial exposomes that promoted and/or had synergy with physical activity to improve metabolic health; (ii), harmful exposomes in which doing physical activity may affect metabolic function or may limit capacity to do physical activity; (iii) environmental determinants of exposomes that had effects on metabolic health that may be independent of physical activity; (iv), and exposures that may be risky or have uncertain or unknown interactions with physical activity (Fig. 1). Finally, we discuss issues around how environments can be better optimised to improve physical activity outcomes for metabolic health, and likely future directions of this field of research.

\section{Physical activity as part of a 'beneficial' exposomes}

\section{Physical activity, green space and natural outdoor environments}

Green spaces or natural outdoor environments (e.g. parklands, bushlands, open spaces, wetlands, rivers, 


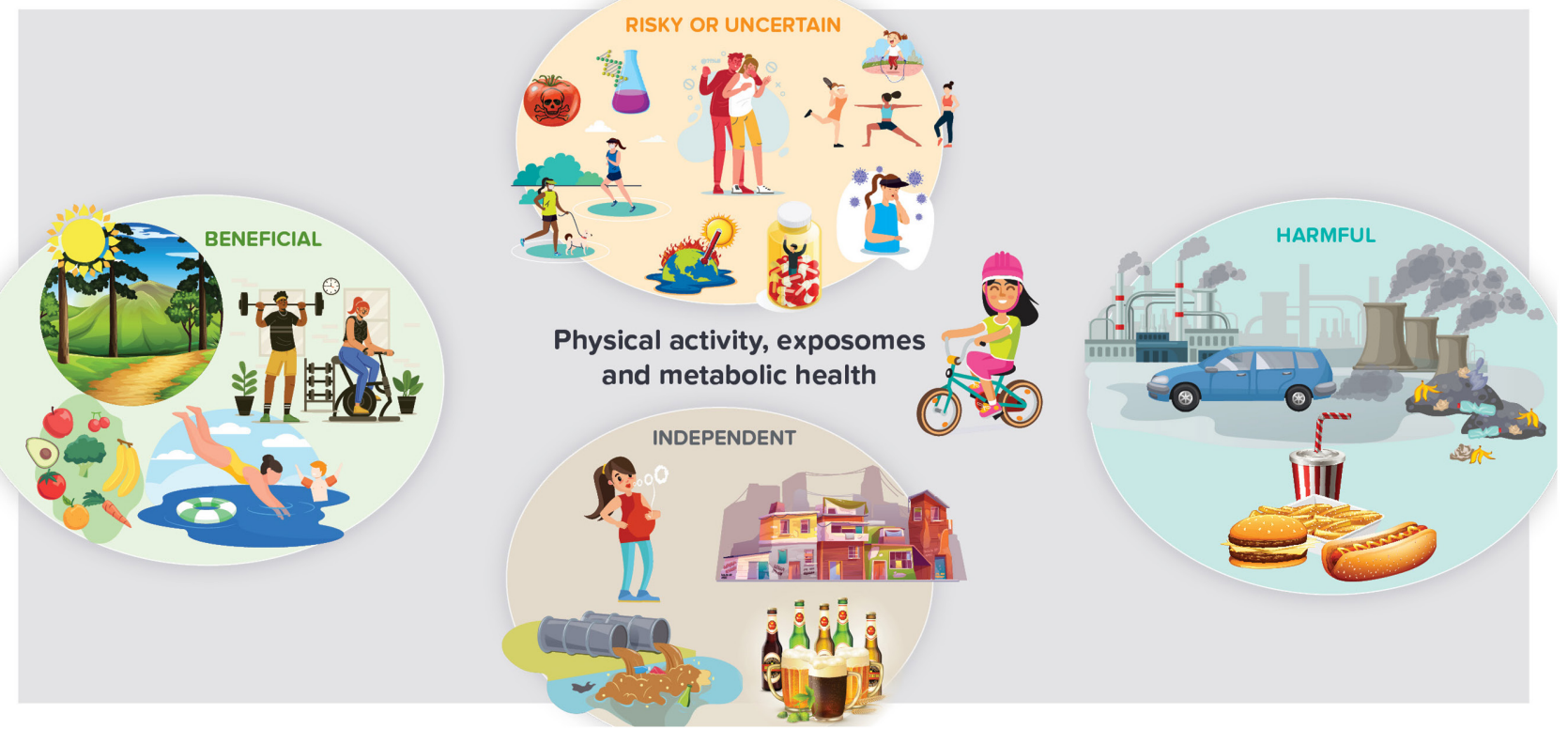

\section{Figure 1}

The impacts of physical activity on metabolic health in differing exposomes (and vice versa). Beneficial exposomes that promoted and/or could have synergy with physical activity to associate with improvements in metabolic health included: natural outdoor environments (green spaces) with little pollution; provision of walking and cycling infrastructure and physical activity facilities (e.g. swimming pools, gyms); capacity for low dose/safe sun exposure; and (access to) healthy diets. Harmful exposomes in which doing physical activity was associated with adverse impacts on metabolic function included: those with polluted environments (particularly air pollution); limited walkability or cycling infrastructure or access to physical activity facilities; and increased access to unhealthy foods (i.e. takeaway or fast foods). Environmental determinants of exposomes identified to be associated with metabolic health outcomes that could have effects on metabolic health independent of physical activity included: maternal and passive smoking; air and organic pollutants; alcohol intake; healthy diets; and living in densely populated areas. Finally, exposomes that may be risky or have uncertain or unknown interactions with physical activity included those that promote: immunosuppression and viral infections (including impacts of pandemicinduced social distancing and lockdowns); increased movement of transposable DNA elements (i.e. transposons); climate change and global warming; endocrine-disrupting chemicals; food contaminants; safety and violence; neglect; addiction and opioid use; and, societal value on sports participation by girls and women.

beaches) provide space for outdoor physical activity, with other proposed benefits for mental health, sleep, social contact, and reduced exposure to urban pollutants such as carbon dioxide $\left(\mathrm{CO}_{2}\right)$, particulate matter, noise and heat (Kumar et al. 2019). Potential risks from green space may include excessive sun exposure (e.g. skin cancer; although this can be prevented by tree canopies, shading and sun-protective behaviours), exposure to airborne allergens (e.g. pollen) and vector-borne diseases (e.g. those transmitted via ticks - Lyme disease) (DonaireGonzalez et al. 2019, Kumar et al. 2019, VanAcker et al. 2019). Other risks of undertaking physical activities, such as jogging, include that done in green spaces located within or in close proximity to urban areas with increased airborne particulate matter (Liu et al. 2019), or biogenic volatile organic compounds (e.g. isoprene), which are precursors to ground-level ozone and secondary organic aerosols (Salmond et al. 2016, Ren et al. 2017). For example, Californian children participating in outdoor team sports in areas of high ground-level ozone had an increased relative risk of developing asthma (McConnell et al. 2002). That said, most health impact monitoring studies suggest that the benefits of physical activity in green spaces outweigh the potential costs of exposure to additional air pollution (Doorley et al. 2015, Mueller et al. 2015). In a study of pregnant women $(n=167)$ and children $(n=183)$ living in three European cities, a 'personalised monitoring kit' was used to characterise personal exposomes, and included measurement of physical activity (via accelerometer), exposure to UV radiation (via dosimeter), traffic noise (via smartphone) and air pollution (via two monitors; one measuring particulate matter $2.5 \mu \mathrm{m}\left(\mathrm{PM}_{2.5}\right)$ levels, the other black carbon) (Donaire-Gonzalez et al. 2019). Significant (but 'low strength'; $\mathrm{r}<0.3)$ correlations between physical activity and the surrounding 'greenness' (normalised greenness vegetation index) or green space (time spent in natural outdoor environments) or UV dose received (but not pollutants) were observed in pregnant participants (Donaire-Gonzalez et al. 2019). These data suggest that 
the physical activity done was associated with exposomes that had natural outdoor environments. This, in turn, may increase an individual's exposure to UV radiation, which may have additional metabolic benefits (Gorman 2020), although this needs to be balanced with the risks of excessive sun exposure. An important limitation of this study was its relatively small sample size.

\section{Physical activity and sun exposure}

Our recent pre-clinical studies point towards potentially metabolically beneficial synergies between physical activity and sun exposure (Allemann et al. 2020). We observed increased expression of mRNAs linked with thermogenesis (Ucp1), fatty acid synthesis (FasN) and insulin signalling (Igf1) in interscapular brown adipose tissue of mice exposed to non-burning UV radiation (1 $\mathrm{kJ} / \mathrm{m}^{2}$ ) and allowed access to running wheels, compared to either treatment alone (Allemann et al. 2020). In other studies, we demonstrated that many of the metabolic benefits of UV radiation occurred through skin release of nitric oxide (Geldenhuys et al. 2014, Fleury et al. 2017, Dhamrait et al. 2020). This process is multiphasic, involving keratinocytes and endothelial cells (Holliman et al. 2017), occurs in human skin (Liu et al. 2014) and may allow for sustained release of nitric oxide for improved physical performance in conjunction with dietary nitrate (Muggeridge et al. 2015). Exposure to UV radiation did not increase the distance run in mice fed a high-fat diet (Allemann et al. 2020). Furthermore, women with 'active sun exposure habits' had a 30\% reduced risk of type 2 diabetes following adjustment for differences in physical activity levels (determined via questionnaire and adjusted for age, BMI, smoking) (Lindqvist et al. 2010), suggesting there are also beneficial effects of sun exposure independent of physical activity for metabolic health. These may include improvements in insulin sensitivity and reductions in adiposity, as observed previously in experimental mice fed a high-fat diet (Geldenhuys et al. 2014, Fleury et al. 2017, Dhamrait et al. 2020). Further research is necessary that measures both sun exposure and physical activity levels at a personal level, as well as other elements of the exposome, to better define their combined impacts on the metabolic health of humans.

\section{Physical activity and diet}

Physical activity and diet combined as lifestyle interventions to prevent and treat metabolic dysfunction are the subjects of much research. Indeed, the relationships between physical activity and diet/nutrition are complex and controversial (Hughes 2014), influenced by the diversity of diet-related 'risk pathways' that range from satiety to the gut microbiome food quality and dietary patterns; determinants of dietary choice; food processing and preparation; and, use of supplements (Mozaffarian 2016, Drewnowski et al. 2020). For example, in an Italian study, increased levels of physical activity was observed in children ( $n=178$ ) with 'normal' weight compared to children with overweight or obesity, with no difference in diet quality observed between these groups (De Giuseppe et al. 2020). The reader is directed to recent reviews that discuss how combining physical activity and diet to treat metabolic dysfunction may promote weight loss, reductions in liver fat, improvements to blood glucose control and fitness, and higher disease remission rates (e.g. for type 2 diabetes) (Aoyama \& Shibata 2020, Magkos et al. 2020, Ross et al. 2020, Savikj \& Zierath 2020). The Mediterranean diet, hypocaloric diet and/or diets that promote caloric restriction are common strategies that are often combined with an increasing physical activity levels as first-line therapy for many metabolic disorders (Pani et al. 2020, Ross et al. 2020). This combined approach has benefits for metabolic health that likely exceed either diet or physical activity interventions on their own (Ross et al. 2020). Other studies point to the speed at which changes in physical activity and diet may affect metabolic health. For example, substantial reductions in step count (limited to 1500 steps/day) combined with a high-caloric diet $(+50 \% \mathrm{kcal})$ reduced insulin sensitivity after 3 days, and caused weight gain after 7 days in healthy young men (Knudsen et al. 2012). However, maintenance of the metabolic benefits of lifestyle interventions is difficult due to hunger and lack of post-meal satiety signals, affecting long-term compliance (Magkos et al. 2020). In addition, a number of individual and environmental factors influence short- and long-term physical activity behaviour change. These include a person's self-efficacy and motivation, physical activity/exercise history, skills and ability to participate in physical activity, and other health behaviours (Trost et al. 2002, Bauman et al. 2012). Environmental influences of physical activity behaviour change include perceived and actual access to required facilities, financial and time barriers as well as the level of social support (Dishman et al. 1985, Sherwood \& Jeffery 2000, Amireault et al. 2013).

How to best combine physical activity and diet as lifestyle strategies to improve metabolic health is an industrious and controversial area of research. Factors that may be important include the types and balance of 
macronutrient intake (i.e. fat, carbohydrate, protein), the nature of physical activity done (i.e. intensity, duration, type, frequency), the timing of activity relative to when meals are eaten, the influence of circadian rhythm, and how to provide advice that is best tailored to an individual's physiology and personal preferences (i.e. precision dietary (Magkos et al. 2020) and physical activity (Bulbul 2020) strategies). Savikj \& Zierath (2020) recently reviewed the evidence around substrate availability provided through the diet and observed that low carbohydrate availability may force the use of stored lipids as fuel sources, promote mitochondrial biogenesis, and increase cardiovascular function and skeletal muscle oxidative capacity in athletes. Conversely, low-intensity exercise may improve glycaemic control post-prandially (after eating); however, there is limited knowledge of the impacts, and potential health risks around limiting substrate availability, or exercising after meals, in people with type 2 diabetes (Savikj \& Zierath 2020). Other studies suggest that exercising in the morning before breakfast may promote long-lasting effects on fat oxidation, compared to exercise done after breakfast (reviewed by Aoyama \& Shibata 2020).

\section{Physical activity and the built environment}

The built environment includes anthropogenic (human) structures, features and facilities in a given area. Elements of the built environment that may promote physical activity include its inherent walkability, the provision of physical activity destinations and resources (e.g. gymnasiums, swimming pools, sports fields), and playgrounds. These are often studied with other elements of the built environment, including type and number of food outlets, population density and socioeconomic status, street connectivity, land use mix, aesthetics and public transport infrastructure. For example, in a study of children ( $n=681,6-12$ year olds) who were classified as living in one of four neighbourhood types (based upon park quality, street networks and connectivity (i.e. walkability), presence of supermarkets or fast food restaurants, and residential density), those living in 'less environmentally supportive' neighbourhood types had higher rates of overweight/obesity (Saelens et al. 2018). These less supportive neighbourhoods were less walkable, had fewer recreation facilities and access to lower-quality nutrition. In other studies, the number of physical activity resources (in given regions) was associated with reduced risk of insulin resistance after adjusting for differences in socioeconomic status (Auchincloss et al. 2008). Importantly, physical activity facilities (e.g. gyms, swimming pools) may reduce obesity risk in areas with fewer green spaces and more takeaway stores (Mason $\mathrm{et}$ al. 2020).

\section{Physical activity may limit metabolic dysfunction caused by adverse exposomes}

\section{Exposomes with air pollution may limit opportunities for physical activity}

Around the world, air pollution varies from clean/'good' (e.g $5 \mu \mathrm{g} / \mathrm{m}^{3} \mathrm{PM}_{2.5}$ (Hobart, Australia) to dirty/'hazardous' (e.g. $500 \mu \mathrm{g} / \mathrm{m}^{3} \mathrm{PM}_{2.5}$ (Cork, Ireland) (data obtained at https://aqicn.org/, 06:00 GMT, 31 August 2020). In a metaanalysis of 7 cohort studies, every unit $\left(\mu \mathrm{g} / \mathrm{m}^{3}\right)$ increase in ambient $\mathrm{PM}_{2.5}$ levels, increased the odds for physical inactivity by $1.1 \%$ (Lu et al. 2015, An et al. 2018b). These findings suggest that hazardous levels of air pollution may have substantial impacts on physical activity. Indeed, extreme levels of air pollution sometimes result in the cancellation of outdoor physical activities that would otherwise be undertaken by school students living in some Chinese cities (Dong et al. 2018). Experimental cycling studies suggest that a range of health outcomes are affected by exercising in conditions with poor air quality, with effects on: brain plasticity, respiration, heart rate, blood pressure, inflammation, thrombosis and coagulation, although findings are mixed ( $\mathrm{Lu}$ et al. 2015, Giorgini et al. 2016, Hankey \& Marshall 2017). Important factors regulating exposure to air pollutants for commuting cyclists likely includes the cycling route (i.e. proximity to roads and areas of industry) and level of exertion undertaken, as well as gender, time-of-day, and season (Shrestha et al. 2020). Detrimental effects on pulmonary and cardiovascular function as well as physical performance have been observed in athletes competing in the Olympic Games in locations with high levels of air pollution (Bos et al. 2014). Health impacts of air pollution are likely linked to increased intake (inhalation/ingestion) of particulate matter and ozone when exercising, due to increased ventilation rates (Bos et al. 2014, Dong et al. 2018, DeFlorio-Barker et al. 2020), reduced mucociliary clearance, increased breathing from the mouth and raised pulmonary diffusion capacity (Giorgini et al. 2016). Particulates may directly affect tissues inducing inflammation and oxidative stress, and/or indirectly causing systemic inflammation through the lungs, eyes and skin (Bos et al. 2014). Effects on brain health have been linked to brain-derived neurotrophic factor, an important myokine released into blood with exercise, 
levels of which were suppressed when physical activity was done in a polluted room (Bos et al. 2011).

\section{Health benefits of physical activity may offset risks of air pollution}

Overall, trade-offs between physical activity and air pollution suggest that there are greater health benefits of shifting towards active forms of transport, which outweigh risks of increased exposure to air pollution (Giorgini et al. 2016, Hankey \& Marshall 2017). This may be locationspecific, with more research needed in regions where air pollution levels are extreme, such as that occurring in some Chinese cities (Lu et al. 2015), or in Australia during severe bushfire events (Bambrick et al. 2011). A further factor regulating the cost-benefit relationship of exercise and air pollution, includes consideration of the type of activity done, for example low impact activities (e.g. gardening) may be may be less protective when air pollution levels are high (Andersen et al. 2015). Furthermore, undertaking low impact activities in these conditions may have negative short-term health impacts, particularly in older individuals with lung disease (Sinharay et al. 2018) or those at-risk of heart disease (Giorgini et al. 2016). This may also be related to how low impact activities can be undertaken for longer periods of time, increasing exposure times, while high impact activities are often shorter in length, but substantially augment inhalation rates to potentially increase pollutant exposure across a shorter timeframe. Conversely, moderate-to-high intensity activities are likely beneficial for healthy people, even when concentrations of pollutants are high (DeFlorio-Barker et al. 2020).

Protective mechanistic pathways induced by physical activity likely involve epigenetic regulation of genes. For example, reduced DNA methylation of the FOXP3 promoter (indicative of higher gene activity) was observed in buccal cells from 'active' compared to 'nonactive' children who were exposed to high levels of black carbon $\left(1200 \mathrm{ng} / \mathrm{m}^{3}\right)$ in New York City (Lovinsky-Desir et al. 2017). This finding is of particular interest as FOXP3 gene expression is highly correlated with the activity and function of regulatory $\mathrm{T}$ cells, which act to suppress inflammatory processes that promote insulin resistance (McLaughlin et al. 2017). In addition to those with preexisting cardiometabolic dysfunction or lung conditions, other at-risk groups include children and adolescents, who have incomplete tissue development and different inhalation rates and body sizes compared to adults (Dong et al. 2018). Children are particularly vulnerable to the effects of air pollution for a variety of physiological and behavioural reasons (Schwartz 2004). For example, they breathe faster than adults (Iliff \& Lee 1952), their respiratory epithelium is more permeable (Bateson \& Schwartz 2007), their breathing 'zones' are closer to the ground where certain pollutants are more common (Burtscher \& Schüepp 2012) and they spend more time outdoors (Cohen Hubal et al. 2000). On a per kilogram of body mass basis, children breathe more air and have greater lung surface areas than adults (Poets et al. 1993, Arcus-Arth \& Blaisdell 2007), facilitating particulate matter inhalation and deposition.

\section{Identifying elements of the exposome which affect metabolic health independent of physical activity}

Statistical approaches have been used to identify important and novel environmental determinants of metabolic health that are independent of physical activity. In the HELIX study of 1301 children (aged 6-11 years) in which data were combined from six European birth cohorts, maternal exposures in pregnancy (smoking), and childhood exposures (passive smoking, air pollutants, residence in densely populated areas, reduced facilities near schools) were associated with increased BMI (Vrijheid et al. 2020). Sensitivity analyses indicated little effect of physical activity (maternal or childhood) levels (measured via questionnaire and corrected using accelerometer data from a subset of participants) on these associations. Similarly, in a case-controlled study of older adults $(n=1779)$, increased incidence of type 2 diabetes was associated with baseline levels of persisting organic pollutants (e.g. poly-chlorinated biphenyls), after adjusting for physical activity (from questionnaire-derived data) and other factors (e.g. BMI, alcohol, smoking) (Wolf et al. 2019).

Physical activity is a key aspect of the 'Mediterranean lifestyle' which includes consumption of a largely plantbased diet (Tuttolomondo et al. 2019). In the PREDIMED study, increased adherence to Mediterranean diet $(n=$ 22,043 adults in Greece) was associated with reduced deaths due to heart disease after controlling for physical activity (questionnaire-derived) amongst other factors (e.g. sex, smoking) (Trichopoulou et al. 2003). This analytical approach may also be useful for identifying underlying mechanisms. For example, alcohol intake (but not physical activity levels measured via questionnaire) was associated with the expression of an oxidative stress marker (DNA strand breaks) in lymphocytes isolated from 
healthy older ( $>40$-year-old) women $(n=62)$ (Goncalves Mota et al. 2017), although this study was limited by its relatively small sample size. Further limitations of these approaches are the frequent use of questionnaires to determine physical activity, which may sometimes be inaccurate, with over-reporting likely influenced by recall and/or social desirability biases, particularly for light or moderate-intensity activities (Strath et al. 2013). Even so, controlling for differences in physical activity (and other known modifiers) may provide evidence to help identify important and novel determinants of metabolic health that have effects independent of physical activity.

\section{Potentially risky, uncertain and unknown interactions of exposomes with physical activity}

\section{Exercise-induced immunosuppression, chronic fatigue illnesses and viral infections}

Excessive or 'arduous' levels of physical activity above recommended levels may compromise immune responses, particularly in athletes, and put individuals at increased risk for infection particularly of the upper respiratory tract (Simpson et al. 2020). This is a controversial area of research, with some hypothesising that it is more the stresses and interactions involved in preparing for and participating in competitions and high-performance events that compromises immunity (Simpson et al. 2020). Immune impacts of excessive exercise may include effects on innate pathways (e.g. natural killer cell function), adaptive processes (e.g. involving $\mathrm{T}$ and $\mathrm{B}$ cells) and increased risk for viral reactivation. Viral infections may also combine with physical activity in (other) unexpected ways to affect metabolic health. For example, infection with adenovirus-36 may prevent weight loss induced by exercise, but these exposures combined for more effective glycaemic control, mediated by improvements to mitochondrial numbers and their integrity in the liver (reviewed by Kim et al. 2020).

Viral infections may also limit our capacity to do physical activity, with COVID-19 (coronavirus disease of 2019)-related chronic fatigue illnesses anecdotally observed in $10 \%$ individuals $\geq 3$ months after acute infection with SARS-CoV-2 (Williams et al. 2020). This is often now referred to as 'long COVID' and could be defined as symptoms (cardiovascular, pulmonary, neurological, psychological) that persist beyond 4 weeks of the initial illness (Datta et al. 2020). Viral-related chronic fatigue illnesses may potentially be exacerbated by physical activity (Williams 2020), with declines in physical function and fitness persisting for up to 2 years post-initial infection with the related coronavirus, SARS$\mathrm{CoV}$ (Rooney et al. 2020). Of additional relevance to metabolic health are the plausible links between viral infections, particularly those linked with chronic fatigue syndrome (Proal \& Marshall 2018), and the development of insulin resistance (Zhao et al. 2012) and type 2 diabetes (Spadigam et al. 2016). Viruses associated with both chronic fatigue syndrome and insulin resistance include those with the capacity to establish long-term persistence, such as Epstein-Barr virus and cytomegalovirus (Proal $\&$ Marshall 2018). The metabolic effects of SARS-CoV-2 infection are yet-to-be fully realised, although there are well-described increased risks of severe COVID-19 for people with obesity, cardiovascular disease and type 2 diabetes (Li et al. 2020, Popkin et al. 2020, Xu et al. 2020), with glycaemic control measures likely reducing the impact of severe COVID-19 events (Marazuela et al. 2020).

Social distancing and isolation strategies used to combat the COVID-19 pandemic may also limit capacity for physical activity, with step-counts from smartphone accelerometers of people living in 187 countries reducing by $>25 \%$, 30 days after the COVID-19 pandemic was declared by the World Health Organisation (11 March 2020) (Tison et al. 2020). There are likely negative consequences and cumulative effects of the COVID19 pandemic on physical activity with positive energy balances hypothesised due to reduced physical activity levels, and increased leisure-based screen time and consumption of unhealthy foods (Martinez-Ferran et al. 2020). It is still largely unknown how these factors combine with other elements of the exposome to affect metabolic health. For example, air pollutant levels during the city-lockdown periods were often reduced (He et al. 2020, Venter et al. 2020), although unexpectedly extreme levels were reported in some locations in China (Le et al. 2020), for likely diverse location-specific impacts on metabolic health.

\section{Physical activity activates LINE-1 transposons}

Related to viruses, are long interspersed element-1 (LINE1) retrotransposons, genetic elements that re-insert and move about the human genome through a 'copy-paste' mechanism (Del Re \& Giorgi 2020). These may be sensors of environmental stress with their activity regulated in different ways by environmental exposures (e.g. heavy metals, carcinogens, drugs, ionising radiation) and social interactions (e.g. maternal care, social isolation) (reviewed 
by Del Re \& Giorgi 2020). Interestingly, physical activity may promote LINE-1 transposon promoter activity in the hippocampus of the brain, as measured in L1-EGFP transgenic mice allowed access (or not) to running wheels (Muotri et al. 2009). The influence of physical activityinduced LINE-1 transposon activity on metabolic health has yet to be characterised.

\section{Understudied interactions with physical activity}

The impacts of changes in temperature - due to global warming and climate change - on physical activity and metabolic health are not well described, although increases in temperature and urbanisation (with shifts to motorised transport) likely reduce physical activity levels (Swinburn et al. 2019). An et al. (2018a) presented a conceptual model linking climate change with the obesity epidemic via urbanisation and other related societal shifts that likely promote physical inactivity. In addition, doing physical activity at higher temperatures may impact metabolic processes such as thermoregulation, via increased thermal strain particularly in at-risk populations (e.g. the elderly (Waldock et al. 2018)). Personal sensors are available to measure an individual's personal exposure to temperature in the same context as physical activity and location for potential use in exposome studies (Asimina et al. 2018). Other understudied exposures include non-air pollutants such as mycotoxins, secondary fungal metabolites that contaminate food. These have been detected at levels in urine that sometimes exceed safety limits in participants $(n=94)$ of the National Food, Nutrition and Physical Activity Survey (2015-16) living in Portugal (Martins et al. 2019). Similarly, widespread contamination of environmental biological and water specimens with pharmaceuticals, pesticides, illicit drugs and drugs of abuse, particularly cocaine, was recently detected across five sites in Suffolk, UK (Miller et al. 2019). These contaminants have been detected in many waterways and wastewaters throughout the world, with seepage into soils and ingestion by aquatic organisms (Yadav et al. 2017). How these events impact metabolic health is not well understood, although metabolic syndrome may occur frequently in people with addiction (Singh Balhara et al. 2018) and drug abuse (Virmani et al. 2007). This could be related to the capacity for some drugs (e.g. anti-psychotics) to interact with reward and energy balance pathways in the brain; however, these are complex drug-receptor interactions, which may be metabolically protective or harmful (Siafis et al. 2018). Importantly, school-based interventions that increase physical activity levels may reduce substance abuse by teenagers (Simonton et al. 2018), with likely additional benefits for metabolic health. In further studies, reduced physical activity levels and increased blood levels of cadmium (a heavy metal) and the inflammatory acutephase reactant, c-reactive protein, were associated with reduced telomere length (a sign of biological ageing) in a study of 461 environmental exposures in the NHANES cohort (1999-2002) (Patel et al. 2017). Findings from preclinical models suggest that exposure to endocrinedisrupting chemicals (e.g. bisphenol A) in early life (in utero and during lactation) may impair basal metabolic rate (respiratory quotient) and physical activity levels in female, but not male mice (Johnson et al. 2015). Increasing physical activity levels has been proposed as a means of overcoming the negative impacts of endocrine-disrupting chemicals; however, more research is needed to determine whether this is indeed the case (Sargis et al. 2019).

Further research is also needed to better understand how physical activity interacts with sociocultural determinants of metabolic health. It is likely that 'safer' neighbourhoods with reduced violence provide environments that support physical activity with positive associations between physical activity levels and neighbourhood safety and social cohesion, as observed in Mexican-Americans $(n=75)$ living in Phoenix, Arizona (Joseph \& Vega-Lopez 2020). Here, there are likely additional considerations of potential 'buffering effects' of more proximal influences on physical activity and other lifestyle risk factors for metabolic health, including genetics and social networks of individuals (family, friends). Furthermore, greater exposure to adverse child experiences (such as abuse, neglect, violence) was associated with a reduced likelihood of participants ( $n=387$, Toronto, Canada) selecting physical activity as a behavioural change goal in adulthood (Maunder et al. 2019), with these individuals likely having less opportunity to establish healthy physical activity and other lifestyle-related behaviours early in life. Personal childhood trauma and exposure to traumatic events may contribute towards potentially addictive behaviours around food, alcohol and prescription drug use, including opioids sometimes prescribed for pain management for people with obesity (Brady \& Back 2012, Sinha 2018, Garami et al. 2019). These addictive behaviours are also associated with increased risk for obesity (Volkow et al. 2013, Traversy \& Chaput 2015, Stokes et al. 2019). A better understanding is needed around the impacts of the 'exposome of addiction' on physical activity and metabolic health including the combined impacts of physical, social 
(e.g. interactions with others with addiction, or availability of support groups) and community (e.g. local attitudes towards addictive behaviours) environments (Stahler et al. 2013), as well as the impact of physical activity as a positive intervention for addictive behaviours. Finally, little research has been done around how societal values placed on the importance of physical activity and sports participation affect metabolic health, particularly in girls and women (Swinburn et al. 2019). As described below, new cohort-based studies are underway to discover the interactive effects of these, and many other environmental influences on metabolic and other health outcomes (Maitre et al. 2018, Jaddoe et al. 2020). Furthermore, future systematic reviews may uncover findings that more clearly delineate the role of sociocultural and other understudied elements of exposomes, and how they interact with physical activity to determine metabolic health.

\section{Optimising environments for better physical activity outcomes}

\section{Indoor vs outdoor environments}

Doing physical activity in indoors environments may sometimes be risky. Concentrations of some air pollutants can be higher in indoor settings, compared to outdoor locations where physical activity takes place (Andrade \& Dominski 2018). These pollutants included carbon monoxide, $\mathrm{CO}_{2}$, nitrogen dioxide $\left(\mathrm{NO}_{2}\right)$, fungi, and particulate matter and occurred in indoor locations such as ice-skating rinks, commercial and school gymnasiums and fitness centres (Andrade \& Dominski 2018). Potential sources of these pollutants included ice-resurfacing machines (for $\mathrm{NO}_{2}$ and particulates), and locations in which a high number of individuals undertake high-intensity activities indoors (for $\mathrm{CO}_{2}$ ). Infection risk, particularly for viruses transmitted via contaminated surfaces or through the air, is likely enhanced in indoor exercise settings (Vardoulakis et al. 2020). Therefore, consideration of ways to limit exposure to indoor pollutants and infection risk through improved management and design of indoor exercise facilities is needed.

Of similar interest are findings of van Veldhoven et al. (2018), who identified substantial increases in exhaled breath levels of water disinfection by-products in adult volunteers following a 40-min swim in an indoor swimming pool. Levels of these by-products strongly correlated with the amount of physical activity (kcal, energy expenditure) undertaken by volunteers, and blood levels of metabolites of the tryptophan pathway (van
Veldhoven et al. 2018). However, it was not possible in that study to differentiate between the effects of physical activity and impacts of exposure to the disinfection by-products. Uncertainties also remain as to whether the same effects would occur in outdoor pool environments, and there may be possible further interactions through sun exposure and/or temperature that could modify the type and concentration of disinfectant by-products in water, as well as physiological responses. Interestingly, metabolites of the tryptophan pathway are endogenous ligands of the aryl hydrocarbon receptor and can be induced by exposure to UV light or synthesised by bacteria, with other known ligands of this receptor including pollutants such as polyphenols (Cella \& Colonna 2015). Tryptophan metabolite-aryl hydrocarbon receptor interactions seem particularly sensitive to these (Cella \& Colonna 2015, Vieyra-Garcia \& Wolf 2018) and other environmental influences, including exercise and diet (e.g. vegetables (Kaiser et al. 2020)). It will be important to assess how exposures come together (in exposomes) to regulate this pathway, with likely impacts on metabolic health (Ghigliotti et al. 2014). These may be directly or indirectly influenced by the capacity of tryptophan metabolite-aryl hydrocarbon receptor interactions to regulate immunity (Cella \& Colonna 2015, Rothhammer \& Quintana 2019), inflammation (Vogel et al. 2020) and oxidative stress (Kaiser et al. 2020).

\section{Better urban environments}

Further consideration is needed in the design of urban environments to create beneficial exposomes for physical activity, particularly around increasing greenness and green spaces (Bos et al. 2014, Lu et al. 2015), and limiting air pollution. Unfortunately, poor air quality is often located in areas of high walkability (Hankey \& Marshall 2017), as demonstrated in nationwide data from the Nurses' Health Study, in which positive correlations between walkability, population density and $\mathrm{PM}_{2.5}$ levels persisted after adjustments were made for differences in socioeconomic status (James et al. 2015). Similarly, commuting cycling networks are often developed alongside major traffic routes (Shrestha et al. 2020). Therefore, planning and construction of cycling infrastructure needs to be done in ways that limit personalised exposure to air pollution (Bos et al. 2014). In a system-dynamics modelling study of Auckland (New Zealand), the best policy scenarios for promoting cycling were tested, in which the impacts of injury, physical activity, fuel costs, air pollution and carbon emissions were assessed over 40 years. The policy 
scenario that predicted the best health and environmental outcomes relative to cost, included provision of infrastructure that physically separated cyclists from urban roads, and instituted speed reductions (by traffic) on local streets (Macmillan et al. 2014). Other elements of the urban environment that could provide better exposomes for physical activity include those that may limit the impacts of air pollution (e.g. public transportation), and, improve walkability (e.g. pathways), safety (e.g. better street lighting) and greenness (e.g. vegetation and tree planting).

\section{Future directions}

\section{International cohort studies and systematic reviews will help better define the influence of exposomes on health}

The HELIX study (of 31,472 mother-child pairs) will have capacity to determine the influence of maternal and child physical activity on adiposity (e.g. BMI, skin-fold), cardiovascular (blood pressure) and other (lung health) outcomes across varying exposomes, characterising built environment (population density and public facility availability), and other urban (traffic, green space, noise), outdoor (ambient UV, air pollutants) and personal exposures (smoking, diet, pollutant and chemical) (Maitre et al. 2018). Similarly, the LIFECYCLE PROJECT-EU Child Cohort Network has recently been formed to examine the effects of exposomes on cardiometabolic (e.g. BMI, body composition, lipids, glucose, insulin) and other health outcomes, for which data will be harmonised from 19 birth cohorts of 250,000 children and parents to better understand the interacting effects of exposures including markers of socioeconomic status, lifestyle and nutrition, and urban environments (Jaddoe et al. 2020). Systematic review and meta-analyses of these new and previously published studies may help better understand how some less welldescribed elements of exposomes interact with physical activity and metabolic health. These will likely require careful formative work to identify keywords and scope beyond those used in this narrative review.

\section{Natural experiments of the impact of built and natural environment-based exposomes on physical activity and metabolic health}

Evaluating the impact of changes to urban design features or related policies (e.g. park revitalisation, new transport infrastructure, congestion charging) on recreational and transport-related physical activity using a natural experimental design is a feasible and recommended alternative when randomised controlled trials are difficult and costly to undertake (Christian et al. 2013). Results from such natural experiments show that people living closer to places where there has been a built infrastructural change (e.g. a new cycle route) have higher cycling rates (Stappers et al. 2018), and urban policy that results in well-connected neighbourhoods with access to local parks of varying sizes increasing local recreational walking (Christian et al. 2017). Built and natural environmental interventions that target improving accessibility and connectivity, traffic and personal safety, and the experience of walking and cycling are likely to have the greatest impact on physical activity levels (Panter et al. 2019) and potentially metabolic health.

\section{Measuring and controlling for genetic variability}

Future studies will likely work towards integrating human genome and exposome data (via systems biology approaches) to better define specific gene-environment interactions and networks to evaluate the impact of personalised influences on metabolic health (Barouki et al. 2018, Jaddoe et al. 2020). Twin studies may also be a means of controlling for genetic variation. In a case study of a single pair of monozygotic twins with discordant physical habits, a twin with chronic endurance training for $>30$ years had increased myosin heavy chain (type 1) development, aerobic capacity $\left(\mathrm{VO}_{2} \mathrm{max}\right)$, a better blood fat and sugar profile, and lower body fat levels, compared to their twin who did not train consistently during that time-frame (Bathgate et al. 2018). While further studies are needed to confirm these findings, examining twins with 'discordant physical habits' may be a novel means of better defining the effects of physical activity in varying exposomes. Another way to control genetic variability is through animal experimentation. Many exposures can be translated from real-world environments into the laboratory, including diet, physical activity (e.g. provision of running wheels), pollutants, smoking, alcohol intake, UV radiation, temperature, circadian rhythm and noise. Clearly, the influence of some human behaviours, social constructs and aspects of the built environment may be less easy to reproduce (e.g. socioeconomic status, poverty, crime, education), and while animal models are extremely helpful to define causality and identify mechanisms, they do not perfectly mimic human physiology and pathology. 


\section{New technologies and tools}

New online tools are being developed that may help researchers better evaluate the interplay between the built environment, diet quality and physical activity on cardiometabolic outcomes. One example is 'KARMA', a web-based interactive tool, which allows participants to selfreport destinations they visit, and anticipates travel routes based on the mode of transportation, which will be combined with accelerometry, food frequency questionnaires, and other data to provide a more complete understanding of participant's exposomes (Drewnowski et al. 2020). Similarly, the rapid uptake of smartphone devices with inbuilt capacity to measure physical activity (e.g. pedometer apps), and, global positioning systems (GPS) enable measurement of a person's physical activity and location in real-time and with geographical information systems (GIS) providing details on their physical environment (Stahler et al. 2013). As described earlier, other researchers have developed 'personalised monitoring kits' to characterise an individual's exposome (Donaire-Gonzalez et al. 2019). Initial findings suggest that ambient measures may correlate well with personalised measurements for some (e.g. personal and ambient levels of particulate matter absorbance), but not all (e.g. personal UV dose compared to ambient UV levels) exposures (Donaire-Gonzalez et al. 2019). However, it is important to recognise that measurement of exposures at a personal level is intrinsically difficult, costly, and maybe burdensome for participants, with potential compliance and privacy issues (e.g. GPS tracking, location-based technologies (Stahler et al. 2013)).

\section{Conclusion}

Exposomes have bidirectional effects on physical activity levels and metabolic health. Beneficial exposomes with green, natural outdoor spaces, physical activity resources and high walkability, promote physical activity and modest sun exposure, may combine with healthy diets to likely limit metabolic dysfunction. Conversely, physical activity may reduce the adverse impacts of high air pollution in some individuals, particularly when done in green spaces. There is more uncertainty around some features of exposomes such as viral infections, which may combine in unexpected ways with physical activity to modulate metabolic health. Future studies will likely provide a more nuanced understanding of the interactions between physical activity, exposomes and metabolic health, potentially with the development of more personalised advice, such as better defining the optimal exposomes for physical activity, particularly for those at-risk of cardiovascular and metabolic dysfunction (Giorgini et al. 2016). Other important considerations will include how advice can be best tailored according to gender, ethnicity and age. However, many different levels of modifiable and non-modifiable factors affect physical activity behaviour, and our personal capacity to maintain or change our exposome may be limited. Similarly, exposomes are not static. A better understanding of how physical activity can be beneficial is needed (i.e. what type, intensity, frequency and duration), particularly to mitigate against the harms of more toxic exposomes, and in countries with high proportions of people living in poverty. Of particular significance is that exposome research brings together researchers and public health advocates that may not always have the same interests but do have the same goal (Swinburn et al. 2019) of driving synergies in improving the metabolic health of many people living in adverse exposomes around the world.

\section{Declaration of interest}

The authors declare that there is no conflict of interest that could be perceived as prejudicing the impartiality of this review.

\section{Funding}

This work was supported by the Telethon Kids Institute.

\section{Author contribution statement}

S G conceived, designed and wrote the first draft of this review. A N L and H E C contributed significantly to content in the 'air pollution'/'understudied interactions with physical activity' and 'introduction'/'diet'/'future directions' sections, respectively. Both provided editorial input throughout the drafting of the review.

\section{Acknowledgement}

The authors thank Tammy Gibbs and Charlize Donovan for graphic design of Fig. 1.

\section{References}

Abboud M, Rybchyn MS, Rizk R, Fraser DR \& Mason RS 2017 Sunlight exposure is just one of the factors which influence vitamin D status. Photochemical and Photobiological Sciences 16 302-313. (https://doi. org/10.1039/c6pp00329j)

Allemann TS, Dhamrait GK, Fleury NJ, Abel TN, Hart PH, Lucas RM, Matthews VB \& Gorman S 2020 Low-dose UV radiation before 
running wheel access activates brown adipose tissue. Journal of Endocrinology 244 473-486. (https://doi.org/10.1530/JOE-19-0470)

Amireault S, Godin G \& Vézina-Im L-A 2013 Determinants of physical activity maintenance: a systematic review and meta-analyses. Health Psychology Review 7 55-91. (https://doi.org/10.1080/17437199.2012. 701060)

Amirfaiz S \& Shahril MR 2019 Objectively measured physical activity, sedentary behavior, and metabolic syndrome in adults: systematic review of observational evidence. Metabolic Syndrome and Related Disorders 17 1-21. (https://doi.org/10.1089/met.2018.0032)

An R, Ji M \& Zhang S 2018a Global warming and obesity: a systematic review. Obesity Reviews 19 150-163. (https://doi.org/10.1111/ obr.12624)

An R, Zhang S, Ji M \& Guan C $2018 b$ Impact of ambient air pollution on physical activity among adults: a systematic review and metaanalysis. Perspectives in Public Health 138 111-121. (https://doi. org/10.1177/1757913917726567)

Andersen ZJ, de Nazelle A, Mendez MA, Garcia-Aymerich J, Hertel O, Tjonneland A, Overvad K, Raaschou-Nielsen O \& Nieuwenhuijsen MJ 2015 A study of the combined effects of physical activity and air pollution on mortality in elderly urban residents: the Danish Diet, Cancer, and Health Cohort. Environmental Health Perspectives 123 557-563. (https://doi. org/10.1289/ehp.1408698)

Andrade A \& Dominski FH 2018 Indoor air quality of environments used for physical exercise and sports practice: systematic review. Journal of Environmental Management 206 577-586. (https://doi.org/10.1016/j. jenvman.2017.11.001)

Aoyama S \& Shibata S 2020 Time-of-day-dependent physiological responses to meal and exercise. Frontiers in Nutrition 7 18. (https://doi. org/10.3389/fnut.2020.00018)

Arcus-Arth A \& Blaisdell RJ 2007 Statistical distributions of daily breathing rates for narrow age groups of infants and children. Risk Analysis 27 97-110. (https://doi.org/10.1111/j.15396924.2006.00862.x)

Asimina S, Chapizanis D, Karakitsios S, Kontoroupis P, Asimakopoulos DN, Maggos T \& Sarigiannis D 2018 Assessing and enhancing the utility of low-cost activity and location sensors for exposure studies. Environmental Monitoring and Assessment 190155. (https://doi.org/10.1007/s10661-018-6537-2)

Auchincloss AH, Diez Roux AV, Brown DG, Erdmann CA \& Bertoni AG 2008 Neighborhood resources for physical activity and healthy foods and their association with insulin resistance. Epidemiology 19 146-157. (https://doi.org/10.1097/EDE.0b013e31815c480)

Autier P, Boniol M, Pizot C \& Mullie P 2014 Vitamin D status and ill health: a systematic review. Lancet: Diabetes and Endocrinology 2 76-89. (https://doi.org/10.1016/S2213-8587(13)70165-7)

Bambrick HJ, Capon AG, Barnett GB, Beaty RM \& Burton AJ 2011 Climate change and health in the urban environment: adaptation opportunities in Australian cities. Asia-Pacific Journal of Public Health 23 (Supplement) 67S-79S. (https://doi. org/10.1177/1010539510391774)

Barouki R, Audouze K, Coumoul X, Demenais F \& Gauguier D 2018 Integration of the human exposome with the human genome to advance medicine. Biochimie 152 155-158. (https://doi.org/10.1016/j biochi.2018.06.023)

Bateson TF \& Schwartz J 2008 Children's response to air pollutants. Journal of Toxicology and Environmental Health: Part A 71 238-243. (https://doi.org/10.1080/15287390701598234)

Bathgate KE, Bagley JR, Jo E, Talmadge RJ, Tobias IS, Brown LE, Coburn JW, Arevalo JA, Segal NL \& Galpin AJ 2018 Muscle health and performance in monozygotic twins with 30 years of discordant exercise habits. European Journal of Applied Physiology 118 2097-2110. (https://doi.org/10.1007/s00421-018-3943-7)

Bauman AE, Reis RS, Sallis JF, Wells JC, Loos RJF, Martin BW \& Lancet Physical Activity Series Working Group 2012 Correlates of physical activity: why are some people physically active and others not? Lancet 380 258-271. (https://doi.org/10.1016/S0140-6736(12)607351)

Bellou V, Belbasis L, Tzoulaki I \& Evangelou E 2018 Risk factors for type 2 diabetes mellitus: an exposure-wide umbrella review of metaanalyses. PLOS ONE 13 e0194127. (https://doi.org/10.1371/journal. pone.0194127)

Bhatnagar A 2017 Environmental determinants of cardiovascular disease. Circulation Research 121 162-180. (https://doi.org/10.1161/ CIRCRESAHA.117.306458)

Booth FW, Roberts CK \& Laye MJ 2012 Lack of exercise is a major cause of chronic diseases. Comprehensive Physiology 2 1143-1211. (https:// doi.org/10.1002/cphy.c110025)

Bos I, Jacobs L, Nawrot TS, de Geus B, Torfs R, Int Panis L, Degraeuwe B \& Meeusen R 2011 No exercise-induced increase in serum BDNF after cycling near a major traffic road. Neuroscience Letters 500 129-132. (https://doi.org/10.1016/j.neulet.2011.06.019)

Bos I, De Boever P, Int Panis L \& Meeusen R 2014 Physical Activity, Air Pollution and the Brain. Sports Medicine 44 1505-1518. (https://10.1007/s40279-014-0222-6)

Bouillon R, Marcocci C, Carmeliet G, Bikle D, White JH, DawsonHughes B, Lips P, Munns CF, Lazaretti-Castro M, Giustina A, et al. 2019 Skeletal and extraskeletal actions of vitamin D: current evidence and outstanding questions. Endocrine Reviews 40 1109-1151. (https:// doi.org/10.1210/er.2018-00126)

Brady KT \& Back SE 2012 Childhood trauma, posttraumatic stress disorder, and alcohol dependence. Alcohol Research: Current Reviews $\mathbf{3 4}$ 408-413.

Bulbul S 2020 Exercise in the treatment of childhood obesity. Turk Pediatri Arsivi 55 2-10. (https://doi.org/10.14744/TurkPediatriArs.2019.60430)

Burtscher H \& Schüepp K 2012 The occurrence of ultrafine particles in the specific environment of children. Paediatric Respiratory Reviews 13 89-94. (https://doi.org/10.1016/j.prrv.2011.07.004)

Cella M \& Colonna M 2015 Aryl hydrocarbon receptor: linking environment to immunity. Seminars in Immunology 27 310-314. (https://doi.org/10.1016/j.smim.2015.10.002)

Christian H, Knuiman M, Bull F, Timperio A, Foster S, Divitini M, Middleton N \& Giles-Corti B 2013 A new urban planning code's impact on walking: the residential environments project. American Journal of Public Health 103 1219-1228. (https://doi.org/10.2105/ AJPH.2013.301230)

Christian H, Knuiman M, Divitini M, Foster S, Hooper P, Boruff B, Bull F \& Giles-Corti B 2017 A longitudinal analysis of the influence of the neighborhood environment on recreational walking within the neighborhood: results from RESIDE. Environmental Health Perspectives 125 077009. (https://doi.org/10.1289/EHP823)

Churilla JR \& Zoeller RF 2008 Physical activity: physical activity and the metabolic syndrome: a review of the evidence. American Journal of Lifestyle Medicine 2 118-125. (https://doi. org/10.1177/1559827607311981)

Cohen Hubal EA, Sheldon LS, Burke JM, McCurdy TR, Berry MR, Rigas ML, Zartarian VG \& Freeman NC 2000 Children's exposure assessment: a review of factors influencing children's exposure, and the data available to characterize and assess that exposure. Environmental Health Perspectives 108 475-486. (https://doi. org/10.1289/ehp.108-1638158)

Datta SD, Talwar A \& Lee JT 2020 A proposed framework and timeline of the spectrum of disease due to SARS-CoV-2 infection: illness beyond acute infection and public health implications. JAMA 324 2251-2252. (https://doi.org/10.1001/jama.2020.22717)

De Giuseppe R, Calcaterra V, Biino G, Manuelli M, Mier NR, Mantelli M, De Filippo M, Cossellu G \& Cena H 2020 Unhealthy lifestyle and oxidative damage in childhood obesity. Eating and Weight Disorders 25 481-486. (https://doi.org/10.1007/s40519-018-0626-7)

DeFlorio-Barker S, Lobdell DT, Stone SL, Boehmer T \& Rappazzo KM 2020 Acute effects of short-term exposure to air pollution while being https://joe.bioscientifica.com

https://doi.org/10.1530/JOE-20-0487 (c) 2021 Society for Endocrinology Published by Bioscientifica Ltd. Printed in Great Britain 
physically active, the potential for modification: a review of the literature. Preventive Medicine 139 106195. (https://doi.org/10.1016/j. ypmed.2020.106195)

Del Re B \& Giorgi G 2020 Long INterspersed element-1 mobility as a sensor of environmental stresses. Environmental and Molecular Mutagenesis 61 465-493. (https://doi.org/10.1002/em.22366)

Dendup T, Feng X, Clingan S \& Astell-Burt T 2018 Environmental risk factors for developing type 2 diabetes mellitus: a systematic review. International Journal of Environmental Research and Public Health 1578. (https://doi.org/10.3390/ijerph15010078)

Dhamrait GK, Panchal K, Fleury NJ, Abel TN, Ancliffe MK, Crew RC, Croft K, Fernandez BO, Minnion M, Hart PH, et al. 2020 Characterising nitric oxide-mediated metabolic benefits of low-dose ultraviolet radiation in the mouse: a focus on brown adipose tissue. Diabetologia 63 179-193. (https://doi.org/10.1007/s00125-019-050225)

Dishman RK, Sallis JF \& Orenstein DR 1985 The determinants of physical activity and exercise. Public Health Reports 100 158-171.

Donaire-Gonzalez D, Curto A, Valentin A, Andrusaityte S, Basagana X, Casas M, Chatzi L, de Bont J, de Castro M, Dedele A, et al. 2019 Personal assessment of the external exposome during pregnancy and childhood in Europe. Environmental Research 174 95-104. (https://doi. org/10.1016/j.envres.2019.04.015)

Dong J, Zhang S, Xia L, Yu Y, Hu S, Sun J, Zhou P \& Chen P 2018 Physical activity, a critical exposure factor of environmental pollution in children and adolescents health risk assessment. International Journal of Environmental Research and Public Health 15 176. (https://doi. org/10.3390/ijerph15020176)

Doorley R, Pakrashi V \& Ghosh B 2015 Quantifying the health impacts of active travel: assessment of methodologies. Transport Reviews $\mathbf{3 5}$ 559-582. (https://doi.org/10.1080/01441647.2015.1037378)

Drewnowski A, Buszkiewicz J, Aggarwal A, Rose C, Gupta S \& Bradshaw A 2020 Obesity and the built environment: a reappraisal. Obesity $\mathbf{2 8}$ 22-30. (https://doi.org/10.1002/oby.22672)

Feng J, Cavallero S, Hsiai T \& Li R 2020 Impact of air pollution on intestinal redox lipidome and microbiome. Free Radical Biology and Medicine 151 99-110. (https://doi.org/10.1016/j. freeradbiomed.2019.12.044)

Fleury N, Feelisch M, Hart PH, Weller RB, Smoothy J, Matthews VB \& Gorman S 2017 Sub-erythemal ultraviolet radiation reduces metabolic dysfunction in already overweight mice. Journal of Endocrinology 233 81-92. (https://doi.org/10.1530/JOE-16-0616)

Fretts AM, Howard BV, McKnight B, Duncan GE, Beresford SA, Calhoun D, Kriska AM, Storti KL \& Siscovick DS 2012 Modest levels of physical activity are associated with a lower incidence of diabetes in a population with a high rate of obesity: the strong heart family study. Diabetes Care 35 1743-1745. (https://doi.org/10.2337/dc11-2321)

Garami J, Valikhani A, Parkes D, Haber P, Mahlberg J, Misiak B, Frydecka D \& Moustafa AA 2019 Examining perceived stress, childhood trauma and interpersonal trauma in individuals with drug addiction. Psychological Reports 122 433-450. (https://doi. org/10.1177/0033294118764918)

Geldenhuys S, Hart PH, Endersby R, Jacoby P, Feelisch M, Weller RB, Matthews V \& Gorman S 2014 Ultraviolet radiation suppresses obesity and symptoms of metabolic syndrome independently of vitamin D in mice fed a high-fat diet. Diabetes 63 3759-3769. (https://doi. org/10.2337/db13-1675)

Ghigliotti G, Barisione C, Garibaldi S, Fabbi P, Brunelli C, Spallarossa P, Altieri P, Rosa G, Spinella G, Palombo D, et al. 2014 Adipose tissue immune response: novel triggers and consequences for chronic inflammatory conditions. Inflammation 37 1337-1353. (https://doi. org/10.1007/s10753-014-9914-1)

Giorgini P, Rubenfire M, Bard RL, Jackson EA, Ferri C \& Brook RD 2016 Air pollution and exercise: a review of the cardiovascular implications for health care professionals. Journal of Cardiopulmonary
Rehabilitation and Prevention 36 84-95. (https://doi.org/10.1097/ HCR.0000000000000139)

Goncalves Mota MP, Santos Z, Soares J, Pereira A, Fonseca S, Peixoto F, Gaivao I \& Oliveira M 2017 Oxidative stress function in women over 40 years of age, considering their lifestyle. Frontiers in Endocrinology 8 48. (https://doi.org/10.3389/fendo.2017.00048)

Gorman S 2020 Sun exposure: an environmental preventer of metabolic dysfunction? Current Opinion in Endocrine and Metabolic Research 11 1-8. (https://doi.org/10.1016/j.coemr.2019.11.001)

Grundy SM, Brewer HB, Cleeman JI, Smith SC, Lenfant C, American Heart Association \& National Heart, Lung, and Blood Institute 2004 Definition of metabolic syndrome: report of the National Heart, Lung, and Blood Institute/American Heart Association conference on scientific issues related to definition. Circulation 109 433-438. (https://doi.org/10.1161/01.CIR.0000111245.75752.C6)

Guinhouya BC, Samouda H, Zitouni D, Vilhelm C \& Hubert H 2011 Evidence of the influence of physical activity on the metabolic syndrome and/or on insulin resistance in pediatric populations: a systematic review. International Journal of Pediatric Obesity 6 361-388. (https://doi.org/10.3109/17477166.2011.605896)

Hankey S \& Marshall JD 2017 Urban form, air pollution, and health. Current Environmental Health Reports 4 491-503. (https://doi. org/10.1007/s40572-017-0167-7)

He G, Pan Y \& Tanaka T 2020 The short-term impacts of COVID-19 lockdown on urban air pollution in China. Nature Sustainability 3 1005-1011. (https://doi.org/10.1038/s41893-020-0581-y)

Holliman G, Lowe D, Cohen H, Felton S \& Raj K 2017 Ultraviolet radiation-induced production of nitric oxide: a multi-cell and multidonor analysis. Scientific Reports 7 11105. (https://doi.org/10.1038/ s41598-017-11567-5)

Hughes D 2014 Food for thought: the complex and controversial interaction between diet and physical activity. British Journal of Sports Medicine 48 1459-1460. (https://doi.org/10.1136/ bjsports-2014-094024)

Iliff A \& Lee VA 1952 Pulse rate, respiratory rate, and body temperature of children between two months and eighteen years of age. Child Development 23 237-245. (https://doi.org/10.2307/1126031)

Jaddoe VWV, Felix JF, Andersen AN, Charles MA, Chatzi L, Corpeleijn E, Donner N, Elhakeem A, Eriksson JG, Foong R, et al. 2020 The LifeCycle Project-EU Child Cohort Network: a federated analysis infrastructure and harmonized data of more than 250,000 children and parents. European Journal of Epidemiology 35 709-724. (https://doi. org/10.1007/s10654-020-00662-z)

James P, Hart JE \& Laden F 2015 Neighborhood walkability and particulate air pollution in a nationwide cohort of women. Environmental Research 142 703-711. (https://doi.org/10.1016/j. envres.2015.09.005)

Johnson SA, Painter MS, Javurek AB, Ellersieck MR, Wiedmeyer CE, Thyfault JP \& Rosenfeld CS 2015 Sex-dependent effects of developmental exposure to bisphenol A and ethinyl estradiol on metabolic parameters and voluntary physical activity. Journal of Developmental Origins of Health and Disease 6 539-552. (https://doi. org/10.1017/S2040174415001488)

Joseph RP \& Vega-Lopez S 2020 Associations of perceived neighborhood environment and physical activity with metabolic syndrome among Mexican-Americans adults: a cross sectional examination. BMC Research Notes 13 306. (https://doi.org/10.1186/s13104-02005143-w)

Kaiser H, Parker E \& Hamrick MW 2020 Kynurenine signaling through the aryl hydrocarbon receptor: implications for aging and healthspan. Experimental Gerontology 130 110797. (https://doi.org/10.1016/j. exger.2019.110797)

Kim J, Na H, Kim JA \& Nam JH 2020 What we know and what we need to know about adenovirus 36-induced obesity. International Journal of Obesity 44 1197-1209. (https://doi.org/10.1038/s41366-020-0536-4) https://joe.bioscientifica.com https://doi.org/10.1530/JOE-20-0487 (c) 2021 Society for Endocrinology Published by Bioscientifica Ltd. Printed in Great Britain 
Knudsen SH, Hansen LS, Pedersen M, Dejgaard T, Hansen J, Hall GV, Thomsen C, Solomon TP, Pedersen BK \& Krogh-Madsen R 2012 Changes in insulin sensitivity precede changes in body composition during 14 days of step reduction combined with overfeeding in healthy young men. Journal of Applied Physiology 113 7-15. (https:// doi.org/10.1152/japplphysiol.00189.2011)

Kumar P, Druckman A, Gallagher J, Gatersleben B, Allison S, Eisenman TS, Hoang U, Hama S, Tiwari A, Sharma A, et al. 2019 The nexus between air pollution, green infrastructure and human health. Environment International 133 105181. (https://doi.org/10.1016/j. envint.2019.105181)

Le Magueresse-Battistoni B, Vidal H \& Naville D 2018 Environmental pollutants and metabolic disorders: the multi-exposure scenario of life. Frontiers in Endocrinology 9 582. (https://doi.org/10.3389/ fendo.2018.00582)

Le T, Wang Y, Liu L, Yang J, Yung YL, Li G \& Seinfeld JH 2020 Unexpected air pollution with marked emission reductions during the COVID-19 outbreak in China. Science 369 702-706. (https://doi.org/10.1126/ science.abb7431)

Li Y, Xu L, Shan Z, Teng W \& Han C 2019 Association between air pollution and type 2 diabetes: an updated review of the literature. Therapeutic Advances in Endocrinology and Metabolism 10 2042018819897046. (https://doi.org/10.1177/2042018819897046)

Li X, Guan B, Su T, Liu W, Chen M, Bin Waleed K, Guan X, Gary T \& Zhu Z 2020 Impact of cardiovascular disease and cardiac injury on in-hospital mortality in patients with COVID-19: a systematic review and meta-analysis. Heart 106 1142-1147. (https://doi.org/10.1136/ heartjnl-2020-317062)

Lindqvist PG, Olsson H \& Landin-Olsson M 2010 Are active sun exposure habits related to lowering risk of type 2 diabetes mellitus in women, a prospective cohort study? Diabetes Research and Clinical Practice 90 109-114. (https://doi.org/10.1016/j.diabres.2010.06.007)

Liu D, Fernandez BO, Hamilton A, Lang NN, Gallagher JMC, Newby DE, Feelisch M \& Weller RB 2014 UVA irradiation of human skin vasodilates arterial vasculature and lowers blood pressure independently of nitric oxide synthase. Journal of Investigative Dermatology 134 1839-1846. (https://doi.org/10.1038/jid.2014.27)

Liu B, He MM, Wu C, Li J, Li Y, Lau NT, Yu JZ, Lau AKH, Fung JCH, Hoi KI, et al. 2019 Potential exposure to fine particulate matter (PM2.5) and black carbon on jogging trails in Macau. Atmospheric Environment 198 23-33. (https://doi.org/10.1016/j. atmosenv.2018.10.024)

Lovinsky-Desir S, Jung KH, Jezioro JR, Torrone DZ, de Planell-Saguer M, Yan B, Perera FP, Rundle AG, Perzanowski MS, Chillrud SN, et al. 2017 Physical activity, black carbon exposure, and DNA methylation in the FOXP3 promoter. Clinical Epigenetics 9 65. (https://doi.org/10.1186/ s13148-017-0364-0)

Lu J, Liang L, Feng Y, Li R \& Liu Y 2015 Air pollution exposure and physical activity in China: current knowledge, public health implications, and future research needs. International Journal of Environmental Research and Public Health 12 14887-14897. (https:// doi.org/10.3390/ijerph121114887)

Macmillan A, Connor J, Witten K, Kearns R, Rees D \& Woodward A 2014 The societal costs and benefits of commuter bicycling: simulating the effects of specific policies using system dynamics modeling. Environmental Health Perspectives 122 335-344. (https://doi. org/10.1289/ehp.1307250)

Magkos F, Hjorth MF \& Astrup A 2020 Diet and exercise in the prevention and treatment of type 2 diabetes mellitus. Nature Reviews: Endocrinology 16 545-555. (https://doi.org/10.1038/s41574020-0381-5)

Maitre L, de Bont J, Casas M, Robinson O, Aasvang GM, Agier L, Andrusaityte S, Ballester F, Basagana X, Borras E, et al. 2018 Human early life exposome (HELIX) study: a European population-based exposome cohort. BMJ Open 8 e021311. (https://doi.org/10.1136/ bmjopen-2017-021311)
Marazuela M, Giustina A \& Puig-Domingo M 2020 Endocrine and metabolic aspects of the COVID-19 pandemic. Reviews in Endocrine and Metabolic Disorders 21 495-507. (https://doi.org/10.1007/s11154020-09569-2)

Martinez-Ferran M, de la Guia-Galipienso F, Sanchis-Gomar F \& ParejaGaleano H 2020 Metabolic impacts of confinement during the COVID-19 pandemic due to modified diet and physical activity habits. Nutrients 12 1549. (https://doi.org/10.3390/nu12061549)

Martins C, Vidal A, De Boevre M, De Saeger S, Nunes C, Torres D, Goios A, Lopes C, Assuncao R \& Alvito P 2019 Exposure assessment of Portuguese population to multiple mycotoxins: the human biomonitoring approach. International Journal of Hygiene and Environmental Health 222 913-925. (https://doi.org/10.1016/j. ijheh.2019.06.010)

Mason KE, Pearce N \& Cummins S 2020 Do neighbourhood characteristics act together to influence BMI? A cross-sectional study of urban parks and takeaway/fast-food stores as modifiers of the effect of physical activity facilities. Social Science and Medicine 261113242. (https://doi.org/10.1016/j.socscimed.2020.113242)

Maunder RG, Tannenbaum DW, Permaul JA, Nutik M, Haber C, Mitri M, Costantini D \& Hunter JJ 2019 The prevalence and clinical correlates of adverse childhood experiences in a cross-sectional study of primary care patients with cardiometabolic disease or risk factors. BMC Cardiovascular Disorders 19 304. (https://doi.org/10.1186/s12872-01901277-3)

McConnell R, Berhane K, Gilliland F, London SJ, Islam T, Gauderman WJ, Avol E, Margolis HG \& Peters JM 2002 Asthma in exercising children exposed to ozone: a cohort study. Lancet 359 386-391. (https://doi. org/10.1016/S0140-6736(02)07597-9)

McGee SL \& Hargreaves M 2020 Exercise adaptations: molecular mechanisms and potential targets for therapeutic benefit. Nature Reviews: Endocrinology 16 495-505. (https://doi.org/10.1038/s41574020-0377-1)

McLaughlin T, Ackerman SE, Shen L \& Engleman E 2017 Role of innate and adaptive immunity in obesity-associated metabolic disease. Journal of Clinical Investigation 127 5-13. (https://doi.org/10.1172/ JCI88876)

Miller TH, Ng KT, Bury ST, Bury SE, Bury NR \& Barron LP 2019 Biomonitoring of pesticides, pharmaceuticals and illicit drugs in a freshwater invertebrate to estimate toxic or effect pressure. Environment International 129 595-606. (https://doi.org/10.1016/j. envint.2019.04.038)

Mozaffarian D 2016 Dietary and policy priorities for cardiovascular disease, diabetes, and obesity: a comprehensive review. Circulation 133 187-225. (https://doi.org/10.1161/ CIRCULATIONAHA.115.018585)

Mueller N, Rojas-Rueda D, Cole-Hunter T, de Nazelle A, Dons E, Gerike R, Götschi T, Int Panis L, Kahlmeier S \& Nieuwenhuijsen M 2015 Health impact assessment of active transportation: a systematic review. Preventive Medicine 76 103-114. (https://doi.org/10.1016/j. ypmed.2015.04.010)

Muggeridge DJ, Sculthorpe N, Grace FM, Willis G, Thornhill L, Weller RB, James PE \& Easton C 2015 Acute whole body UVA irradiation combined with nitrate ingestion enhances time trial performance in trained cyclists. Nitric Oxide: Biology and Chemistry 48 3-9. (https:// doi.org/10.1016/j.niox.2014.09.158)

Muotri AR, Zhao C, Marchetto MC \& Gage FH 2009 Environmental influence on L1 retrotransposons in the adult hippocampus. Hippocampus 19 1002-1007. (https://doi.org/10.1002/hipo.20564)

Nieuwenhuijsen MJ 2016 Urban and transport planning, environmental exposures and health-new concepts, methods and tools to improve health in cities. Environmental Health: A Global Access Science Source $\mathbf{1 5}$ (Supplement 1) 38. (https://doi.org/10.1186/s12940-016-0108-1)

Pani A, Gironi I, Di Vieste G, Mion E, Bertuzzi F \& Pintaudi B 2020 From prediabetes to type 2 diabetes mellitus in women with polycystic ovary syndrome: lifestyle and pharmacological management 
International Journal of Endocrinology 2020 6276187. (https://doi. org $/ 10.1155 / 2020 / 6276187)$

Panter J, Guell C, Humphreys D \& Ogilvie D 2019 Title: can changing the physical environment promote walking and cycling? A systematic review of what works and how. Health and Place 58 102161. (https:// doi.org/10.1016/j.healthplace.2019.102161)

Patel CJ, Manrai AK, Corona E \& Kohane IS 2017 Systematic correlation of environmental exposure and physiological and self-reported behaviour factors with leukocyte telomere length. International Journal of Epidemiology 46 44-56. (https://doi.org/10.1093/ije/ dyw043)

Poets CF, Stebbens VA, Samuels MP \& Southall DP 1993 Oxygen saturation and breathing patterns in children. Pediatrics 92 686-690.

Popkin BM, Du S, Green WD, Beck MA, Algaith T, Herbst CH, Alsukait RF, Alluhidan M, Alazemi N \& Shekar M 2020 Individuals with obesity and COVID-19: a global perspective on the epidemiology and biological relationships. Obesity Reviews 21 e13128. (https://doi. org/10.1111/obr.13128)

Proal A \& Marshall T 2018 Myalgic encephalomyelitis/chronic fatigue syndrome in the era of the human microbiome: persistent pathogens drive chronic symptoms by interfering with host metabolism, gene expression, and immunity. Frontiers in Pediatrics 6 373. (https://doi. org/10.3389/fped.2018.00373)

Rappaport SM 2011 Implications of the exposome for exposure science. Journal of Exposure Science and Environmental Epidemiology 21 5-9. (https://doi.org/10.1038/jes.2010.50)

Rattray NJW, Deziel NC, Wallach JD, Khan SA, Vasiliou V, Ioannidis JPA \& Johnson CH 2018 Beyond genomics: understanding exposotypes through metabolomics. Human Genomics 12 4. (https://doi. org/10.1186/s40246-018-0134-x)

Ren Y, Qu Z, Du Y, Xu R, Ma D, Yang G, Shi Y, Fan X, Tani A, Guo P, et al. 2017 Air quality and health effects of biogenic volatile organic compounds emissions from urban green spaces and the mitigation strategies. Environmental Pollution 230 849-861. (https://doi. org/10.1016/j.envpol.2017.06.049)

Rooney S, Webster A \& Paul L 2020 Systematic review of changes and recovery in physical function and fitness after severe acute respiratory syndrome-related coronavirus infection: implications for COVID19 rehabilitation. Physical Therapy 100 1717-1729. (https://doi. org/10.1093/ptj/pzaa129)

Ross R, Soni S \& Houle SA 2020 Negative energy balance induced by exercise or diet: effects on visceral adipose tissue and liver fat. Nutrients 12 891. (https://doi.org/10.3390/nu12040891)

Rothhammer V \& Quintana FJ 2019 The aryl hydrocarbon receptor: an environmental sensor integrating immune responses in health and disease. Nature Reviews: Immunology 19 184-197. (https://doi. org/10.1038/s41577-019-0125-8)

Saelens BE, Glanz K, Frank LD, Couch SC, Zhou C, Colburn T \& Sallis JF 2018 Two-year changes in child weight status, diet, and activity by neighborhood nutrition and physical activity environment. Obesity 26 1338-1346. (https://doi.org/10.1002/oby.22247)

Salmond JA, Tadaki M, Vardoulakis S, Arbuthnott K, Coutts A, Demuzere M, Dirks KN, Heaviside C, Lim S, Macintyre H, et al. 2016 Health and climate related ecosystem services provided by street trees in the urban environment. Environmental Health: A Global Access Science Source 15 (Supplement 1) 36. (https://doi.org/10.1186/s12940016-0103-6)

Sargis RM, Heindel JJ \& Padmanabhan V 2019 Interventions to address environmental metabolism-disrupting chemicals: changing the narrative to empower action to restore metabolic health. Frontiers in Endocrinology 10 33. (https://doi.org/10.3389/fendo.2019.00033)

Savikj M \& Zierath JR 2020 Train like an athlete: applying exercise interventions to manage type 2 diabetes. Diabetologia 63 1491-1499. (https://doi.org/10.1007/s00125-020-05166-9)

Schwartz J 2004 Air pollution and children's health. Pediatrics 113 (Supplement) 1037-1043
Sherwood NE \& Jeffery RW 2000 The behavioral determinants of exercise: implications for physical activity interventions. Annual Review of Nutrition 20 21-44. (https://doi.org/10.1146/annurev.nutr.20.1.21)

Shrestha A, Mullins B, Zhao Y, Selvey LA \& Rumchev K 2020 Exposure to air pollutants among cyclists: a comparison of different cycling routes in Perth, Western Australia. Air Quality, Atmosphere and Health 13 1023-1034. (https://doi.org/10.1007/s11869-020-00850-6)

Siafis S, Tzachanis D, Samara M \& Papazisis G 2018 Antipsychotic drugs: from receptor-binding profiles to metabolic side effects. Current Neuropharmacology 16 1210-1223. (https://doi.org/10.2174/15701 59X15666170630163616)

Simonton AJ, Young CC \& Johnson KE 2018 Physical activity interventions to decrease substance use in youth: a review of the literature. Substance Use and Misuse 53 2052-2068. (https://doi.org/10. 1080/10826084.2018.1452338)

Simpson RJ, Campbell JP, Gleeson M, Krüger K, Nieman DC, Pyne DB, Turner JE \& Walsh NP 2020 Can exercise affect immune function to increase susceptibility to infection? Exercise Immunology Review 26 $8-22$.

Singh Balhara YP, Jain R, Kuppili PP, Shukla A, Chawla N \& Gupta R 2018 Which criteria to use to identify metabolic syndrome among patients with addictive disorders?: observations among patients with alcohol and opioid dependence syndrome. Indian Journal of Endocrinology and Metabolism 22 565-568. (https://doi.org/10.4103/ijem.IJEM_617_17)

Sinha R 2018 Role of addiction and stress neurobiology on food intake and obesity. Biological Psychology 131 5-13. (https://doi.org/10.1016/j. biopsycho.2017.05.001)

Sinharay R, Gong J, Barratt B, Ohman-Strickland P, Ernst S, Kelly FJ, Zhang JJ, Collins P, Cullinan P \& Chung KF 2018 Respiratory and cardiovascular responses to walking down a traffic-polluted road compared with walking in a traffic-free area in participants aged 60 years and older with chronic lung or heart disease and age-matched healthy controls: a randomised, crossover study. Lancet 391 339-349. (https://doi.org/10.1016/S0140-6736(17)32643-0)

Spadigam A, Dhupar A, Syed S \& Saluja TS 2016 Diabetes, EpsteinBarr virus and extranodal natural killer/T-cell lymphoma in India: unravelling the plausible nexus. Indian Journal of Medical and Paediatric Oncology 37 6-13. (https://doi.org/10.4103/09715851.177002)

Stahler GJ, Mennis J \& Baron DA 2013 Geospatial technology and the 'exposome': new perspectives on addiction. American Journal of Public Health 103 1354-1356. (https://doi.org/10.2105/AJPH.2013.301306)

Stappers NEH, Van Kann DHH, Ettema D, De Vries NK \& Kremers SPJ 2018 The effect of infrastructural changes in the built environment on physical activity, active transportation and sedentary behavior - a systematic review. Health and Place 53 135-149. (https://doi. $\operatorname{org} / 10.1016 /$ j.healthplace.2018.08.002)

Stokes A, Berry KM, Collins JM, Hsiao CW, Waggoner JR, Johnston SS, Ammann EM, Scamuffa RF, Lee S, Lundberg DJ, et al. 2019 The contribution of obesity to prescription opioid use in the United States. Pain 160 2255-2262. (https://doi.org/10.1097/j. pain.0000000000001612)

Strath SJ, Kaminsky LA, Ainsworth BE, Ekelund U, Freedson PS, Gary RA, Richardson CR, Smith DT, Swartz AM \& American Heart Association Physical Activity Committee of the Council on Lifestyle and Cardiometabolic Health and Cardiovascular, Exercise, Cardiac Rehabilitation and Prevention Committee of the Council on Clinical Cardiology, and Council, American Heart Association Physical Activity Committee 2013 Guide to the assessment of physical activity: clinical and research applications: a scientific statement from the American Heart Association. Circulation 128 2259-2279. (https://doi. org/10.1161/01.cir.0000435708.67487.da)

Sun X, Cao ZB, Taniguchi H, Tanisawa K \& Higuchi M 2017 Effect of an acute bout of endurance exercise on serum 25(OH)D concentrations in young adults. Journal of Clinical Endocrinology and Metabolism 102 3937-3944. (https://doi.org/10.1210/jc.2017-00146) https://joe.bioscientifica.com https://doi.org/10.1530/JOE-20-0487 (c) 2021 Society for Endocrinology Published by Bioscientifica Ltd. Printed in Great Britain 
Sun X, Cao ZB, Tanisawa K, Taniguchi H, Kubo T \& Higuchi M 2018 Effects of chronic endurance exercise training on serum $25(\mathrm{OH})$ D concentrations in elderly Japanese men. Endocrine 59 330-337. (https://doi.org/10.1007/s12020-017-1478-z)

Swinburn BA, Kraak VI, Allender S, Atkins VJ, Baker PI, Bogard JR, Brinsden H, Calvillo A, De Schutter O, Devarajan R, et al. 2019 The global syndemic of obesity, undernutrition, and climate change: the lancet commission report. Lancet 393 791-846. (https://doi. org/10.1016/S0140-6736(18)32822-8)

Thyfault JP \& Bergouignan A 2020 Exercise and metabolic health: beyond skeletal muscle. Diabetologia 63 1464-1474. (https://doi.org/10.1007/ s00125-020-05177-6)

Tison GH, Avram R, Kuhar P, Abreau S, Marcus GM, Pletcher MJ \& Olgin JE 2020 Worldwide effect of COVID-19 on physical activity: a descriptive study. Annals of Internal Medicine 173 767-770. (https:// doi.org/10.7326/M20-2665)

Traversy G \& Chaput JP 2015 Alcohol consumption and obesity: an update. Current Obesity Reports 4 122-130. (https://doi.org/10.1007/ s13679-014-0129-4)

Trichopoulou A, Costacou T, Bamia C \& Trichopoulos D 2003 Adherence to a Mediterranean diet and survival in a Greek population. New England Journal of Medicine 348 2599-2608. (https://doi.org/10.1056/ NEJMoa025039)

Trost SG, Owen N, Bauman AE, Sallis JF \& Brown W 2002 Correlates of adults' participation in physical activity: review and update. Medicine and Science in Sports and Exercise 34 1996-2001. (https://doi. org/10.1097/00005768-200212000-00020)

Tuttolomondo A, Simonetta I, Daidone M, Mogavero A, Ortello A \& Pinto A 2019 Metabolic and vascular effect of the Mediterranean diet. International Journal of Molecular Sciences 20 4716. (https://doi org/10.3390/ijms20194716)

van Veldhoven K, Keski-Rahkonen P, Barupal DK, Villanueva CM, Font-Ribera L, Scalbert A, Bodinier B, Grimalt JO, Zwiener C, Vlaanderen J, et al. 2018 Effects of exposure to water disinfection by-products in a swimming pool: a metabolome-wide association study. Environment International 111 60-70. (https://doi.org/10.1016/j. envint.2017.11.017)

VanAcker MC, Little EAH, Molaei G, Bajwa WI \& Diuk-Wasser MA 2019 Enhancement of risk for Lyme disease by landscape connectivity, New York, New York, USA. Emerging Infectious Diseases 25 1136-1143. (https://doi.org/10.3201/eid2506.181741)

Vardoulakis S, Sheel M, Lal A \& Gray D 2020 COVID-19 environmental transmission and preventive public health measures. Australian and New Zealand Journal of Public Health 44 333-335. (https://doi. org/10.1111/1753-6405.13033)

Venter ZS, Aunan K, Chowdhury S \& Lelieveld J 2020 COVID-19 lockdowns cause global air pollution declines. PNAS $\mathbf{1 1 7}$ 18984-18990. (https://doi.org/10.1073/pnas.2006853117)

Vieyra-Garcia PA \& Wolf P 2018 From early immunomodulatory triggers to immunosuppressive outcome: therapeutic implications of the complex interplay Between the wavebands of sunlight and the skin. Frontiers in Medicine 5 232. (https://doi.org/10.3389/fmed.2018.00232)

Virmani A, Binienda ZK, Ali SF \& Gaetani F 2007 Metabolic syndrome in drug abuse. Annals of the New York Academy of Sciences 1122 50-68. (https://doi.org/10.1196/annals.1403.004)
Vogel CFA, Van Winkle LS, Esserd C \& Haarmann-Stemmann T 2020 The aryl hydrocarbon receptor as a target of environmental stressors - implications for pollution mediated stress and inflammatory responses. Redox Biology 34 101530. (https://doi.org/10.1016/j. redox.2020.101530)

Volkow ND, Wang GJ, Tomasi D \& Baler RD 2013 Obesity and addiction: neurobiological overlaps. Obesity Reviews 14 2-18. (https://doi. org/10.1111/j.1467-789X.2012.01031.x)

Vrijheid M, Fossati S, Maitre L, Marquez S, Roumeliotaki T, Agier L, Andrusaityte S, Cadiou S, Casas M, de Castro M, et al. 2020 Early-life environmental exposures and childhood obesity: an exposome-wide approach. Environmental Health Perspectives 128 67009. (https://doi. org/10.1289/EHP5975)

Waldock KAM, Hayes M, Watt PW \& Maxwell NS 2018 Physiological and perceptual responses in the elderly to simulated daily living activities in UK summer climatic conditions. Public Health 161 163-170. (https://doi.org/10.1016/j.puhe.2018.04.012)

Wild CP 2005 Complementing the genome with an 'exposome': the outstanding challenge of environmental exposure measurement in molecular epidemiology. Cancer Epidemiology, Biomarkers and Prevention 14 1847-1850. (https://doi.org/10.1158/1055-9965.EPI-050456)

Williams F 2020 The conversation: Coronavirus: why are some people experiencing long-term fatigue? London, UK: The Conversation. (available at: https://theconversation.com/coronavirus-why-are-somepeople-experiencing-long-term-fatigue-141405)

Williams FMK, Muirhead N \& Pariante C 2020 Covid-19 and chronic fatigue. BMJ $370 \mathrm{~m} 2922$. (https://doi.org/10.1136/bmj.m2922)

Wolf K, Bongaerts BWC, Schneider A, Huth C, Meisinger C, Peters A, Schneider A, Wittsiepe J, Schramm KW, Greiser KH, et al. 2019 Persistent organic pollutants and the incidence of type 2 diabetes in the CARLA and KORA cohort studies. Environment International 129 221-228. (https://doi.org/10.1016/j.envint.2019.05.030)

Xu L, Mao Y \& Chen G 2020 Risk factors for 2019 novel coronavirus disease (COVID-19) patients progressing to critical illness: a systematic review and meta-analysis. Aging 12 12410-12421. (https:// doi.org/10.18632/aging.103383)

Yadav MK, Short MD, Aryal R, Gerber C, van den Akker B \& Saint CP 2017 Occurrence of illicit drugs in water and wastewater and their removal during wastewater treatment. Water Research 124 713-727. (https://doi.org/10.1016/j.watres.2017.07.068)

Yang BY, Fan S, Thiering E, Seissler J, Nowak D, Dong GH \& Heinrich J 2020 Ambient air pollution and diabetes: a systematic review and meta-analysis. Environmental Research 180 108817. (https://doi. org/10.1016/j.envres.2019.108817)

Zhang D, Liu X, Liu Y, Sun X, Wang B, Ren Y, Zhao Y, Zhou J, Han C, Yin L, et al. 2017 Leisure-time physical activity and incident metabolic syndrome: a systematic review and dose-response metaanalysis of cohort studies. Metabolism: Clinical and Experimental $\mathbf{7 5}$ 36-44. (https://doi.org/10.1016/j.metabol.2017.08.001)

Zhao L, Chen YX, Varghese Z, Huang AL, Tang RK, Jia B, Moorhead JF, Gong JP \& Ruan XZ 2012 Murine gamma herpes virus 68 infection promotes fatty liver formation and hepatic insulin resistance in C57BL/6J mice. Hepatology International 6 520-530. (https://doi. org/10.1007/s12072-011-9283-x)

Received in final form 16 December 2020

Accepted 1 March 2021

Accepted Manuscript published online 2 March 2021 https://joe.bioscientifica.com https://doi.org/10.1530/JOE-20-0487
(C) 2021 Society for Endocrinology Published by Bioscientifica Ltd. Printed in Great Britain 